\title{
COMUNICACÕES
}

\section{First report of Tomato mottle leaf curl virus infecting tomato in São Paulo State, Brazil}

\author{
Alexandre Levi Rodrigues Chaves ${ }^{1}$, Marcelo Eiras ${ }^{1}$, Leilane Karam Rodrigues ${ }^{1}$, Alyne de Fátima Ramos ${ }^{1}$, Addolorata \\ Colariccio $^{1}$
}

${ }^{1}$ Instituto Biológico, CEP 04014-900, São Paulo, SP, Brasil

Autor para correspondência: Alexandre Levi R. Chaves (chaves@biologico.sp.gov.br)

Data de chegada: 02/06/2017. Aceito para publicação em: 18/07/2017

$10.1590 / 0100-5405 / 175450$

Diseases caused by several species of the genus Begomovirus (family Geminiviridae) affect the tomato (Solanum lycopersicum) production worldwide. These viruses are transmitted to dicotyledonous in a circulative (non-propagative) manner by the cryptic species complex of Bemisia tabaci (Hemiptera: Aleyrodidae) (De Barro et al., Annual Review of Entomology, v.56, p.1-19, 2011). About eighty species of begomoviruses have already been described in tomato worldwide (Brown et al., Archives of Virology, v.160, p.1593-1619, 2015). In Brazil, begomoviruses started to cause losses to tomato producers in the early 1990's, with the introduction of B. tabaci "biotype B" (Fernandes et al., Virus Genes, v.36, p.251-258, 2008). Brazil is the largest center for begomovirus diversity, where, to date, fourteen recognized species of tomato-infecting begomoviruses have already been described (Inoue-Nagata et al., Horticultura Brasileira, v.34, p. 8-18, 2016); however, the most common species are: Tomato severe rugose virus (ToSRV), a bipartite species of widespread occurrence, reported in Goiás, Minas Gerais and São Paulo; Tomato chlorotic mottle virus (ToCMoV), a bipartite species of minor importance, already reported in Bahia, Goiás and Pernambuco; and Tomato mottle leaf curl virus (ToMoLCV), a monopartite species of major importance especially for the northeast region, reported in Bahia, Distrito Federal, Espírito Santo, Minas Gerais, Rio de Janeiro, Paraíba and Pernambuco. There is evidence that these species have high recombination capacity, which can frequently change begomovirus population structure in a given region (Rocha et al., Journal of Virology, v.87, p.5784-5799,
2013). Samples of tomato leaves showing severe chlorosis, from the municipality of Santo Antônio da Posse, east São Paulo State (Figure 1), were subjected to mechanical transmission to several host plants (solanaceous), as well as DNA extraction and PCR with primers specific to begomoviruses (Rojas et al., Plant Disease, v.77, p.340-347, 1993). The virus was not mechanically transmitted. DNA fragments with ca. 1,500 bp were amplified, sequenced and compared to other sequences deposited in the GenBank, revealing high identity to ToMoLCV Brazilian isolates. Comparisons of the nucleotide sequence of this isolate, named ToMoLCV/SP, showed $98 \%$ similarity with another ToMoLCV tomato isolate from Minas Gerais State (KC706616). ToMoLCV isolates from Bahia, Paraíba, Pernambuco and Distrito Federal showed about 88 to $97 \%$ similarity with ToMoLCV/SP. The area from where ToMoLCV/SP isolate was collected is close to south Minas Gerais State, a large tomato producer region, and, together with intense flocks of whiteflies, may be associated with the occurrence of ToMoLCV in the state of São Paulo. The potential emergency of new begomovirus species, resulting from recombination between ToMoLCV and Tomato yellow vein streak virus (ToYVSV), was already reported in tomato plants from Distrito Federal (Inoue-Nagata et al., Pesquisa Agropecuária Brasileira, v. 87, p. 1329-1332, 2006). ToYVSV is not a common species but is recurrent in São Paulo State (Colariccio et al., Journal Plant Pathology, v.89, p.585-390, 2007), and its association with ToMoLCV may, in the short-term, originate an aggressive complex of begomovirus species.
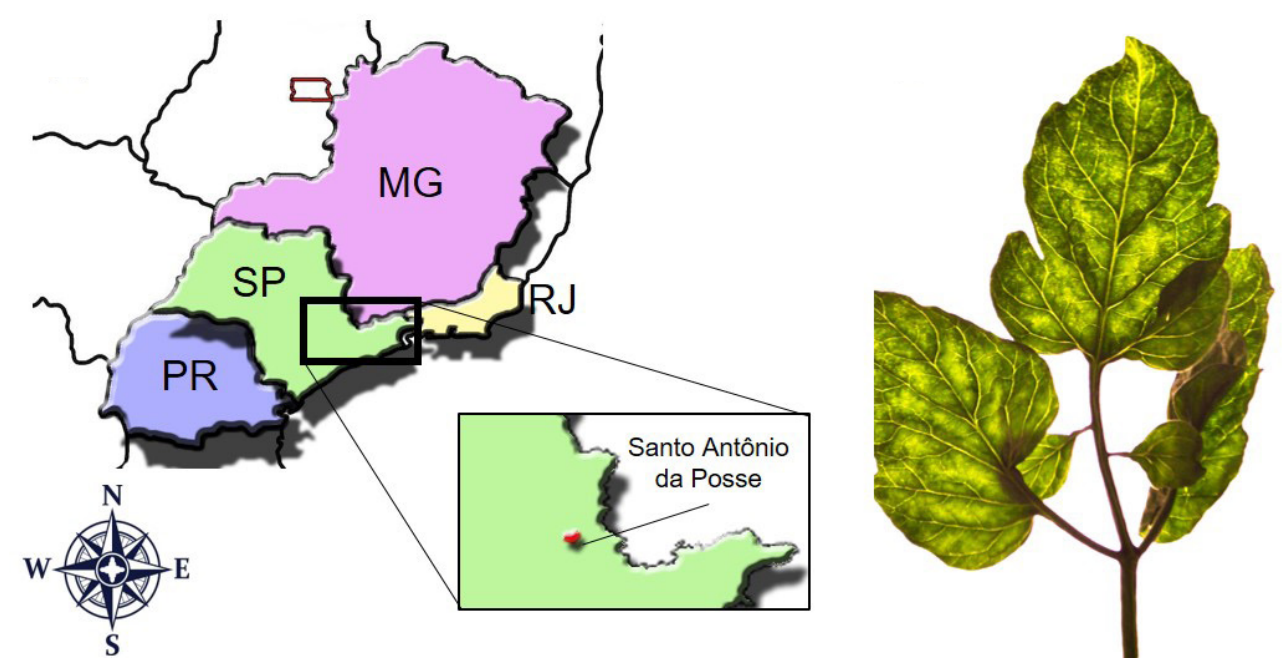

Figure 1. Map showing the location of Santo Antônio da Posse in the state of São Paulo, SP (left), where tomato samples with severe chlorosis symptoms induced by ToMoLCV (rigth) were collected. 